Submission Link. Specific instructions for abstract/video submission are located on the submission Web site, including how to submit graphs or charts.

Authors submitting abstracts/videos for AORTIC SYMPOSIUM 2010 must use electronic submission ONLY.

Abstracts/Videos must be received by Friday, December 11, 2009, by 11:59 PM Eastern Standard Time.

Visit www.aats.org/aortic to learn more about Aortic Symposium 2010.

\section{AATS Meetings and Sponsored Events}

\section{September}

September 10-12, 2009

Heart Valve Summit: Medical, Surgical and Interventional Decision-Making

Chicago Marriott Downtown Magnificent Mile

Chicago, Illinois, USA

*Register online at www.aats.org/valve

\section{February}

February 5-9, 2010

The Tenth Annual International Symposium on Congenital Heart Disease

Renaissance Vinoy Resort

St Petersburg, Florida, USA

\section{April}

April 29-30, 2010

Aortic Symposium 2010

Sheraton New York Hotel and Towers

New York City, New York, USA

May

May 1-5, 2010

AATS 90th Annual Meeting

Metro Toronto Convention Centre

Toronto, Ontario, Canada

\section{AATS Academy Applications Now} Available

Thursday Evening and Friday, April 29 \& 30, 2010, Toronto, ON, Canada (Held immediately prior to the AATS Annual Meeting)

Applications are now available for the 2010 AATS Academy. The AATS Academy is an intensive didactic and interactive program for surgeons showing significant promise as potential future division chiefs or who have recently assumed the role of division chief. For additional information regarding the Academy please visit www.aats.org. Interested applicants should meet the following qualifications before applying:

- Achieved the rank of Associate Professor

- Active/successful clinical surgeon

- Evidence of local institutional and/or state/regional leadership ability

- Evidence of academic productivity including peer-reviewed publications and presentations at regional or national scientific meetings

- Funded research is preferable but not essential

Applications for consideration must be submitted electronically at www.aats.org by December 1, 2009. Academy participants will be selected by the Academy Committee and notified no later than February 5, 2010. The number of available slots is limited.

\section{Applications for Membership Now Available Online}

Applications for membership in the Association are now available online at www.aats.org. Interested applicants are encouraged to review the membership requirements and guidelines on the AATS Web site.

To apply for membership, a current member of the Association must act as the primary sponsor by initiating the application process in the Members Only area of the AATS Web site. Applications must be received by November 30, 2009, for consideration. All applications received after that deadline will be automatically deferred until 2010 .

\section{The Western Thoracic Surgical Association}

\section{Applications for Membership}

Applications for membership in the Association must be received by the Membership Committee Chair no later than March 1, 2010 to be considered at the 2010 Annual Meeting. Applicants must be sponsored by three members of the Association who are not members of the Membership
Committee. Application forms will be issued only to sponsoring members.

Address correspondence to:

Chair, Membership Committee

The Western Thoracic Surgical Association

900 Cummings Center

Suite 221-U

Beverly, MA 01915

978-927-8330; fax: 978-524-8890

wtsa@prri.com 